\title{
FINE COAL BENEFICIATION BY PILOT COLUMN FLOTATION
}

\author{
N. Vasumathi' ${ }^{1 \#}$, T.V. Vijaya Kumar ${ }^{1}$, K. Prasad ${ }^{2}$, S. Subba Rao ${ }^{1}$, \\ S. Prabhakar ${ }^{1}$ G. Bhaskar Raju ${ }^{1}$
}

${ }^{1}$ CSIR - National Metallurgical Laboratory Madras Centre, CSIR Road, Taramani, TTTI (P.O), Chennai-600113, India

${ }^{2} \mathrm{M} / \mathrm{s}$ Tata Steel, Jamshedpur, CSIR Jamshedpur-831001, India

(Received: February 27, 2018; Accepted: May 31,2018)

\begin{abstract}
Beneficiation of coal fines with high ash content was attempted in an operating coal preparation plant by retrofitting a $0.5 \mathrm{~m}$ diameter pilot plant scale flotation column in the circuit. The collector and frother dosage were optimized as $0.680 \mathrm{~kg} / \mathrm{t}$ and $0.058 \mathrm{~kg} / \mathrm{t}$ respectively. At these reagent conditions the operating parameters of pilot scale flotation column were also optimized. The maximum yield of the froth obtained was $67.5 \%$ at the targeted ash level of $14 \%$ from a feed of $25 \%$ ash content. This was obtained at the operating parameters of $0.85 \mathrm{~cm} / \mathrm{s}$ superficial air flow velocity, $0.57 \mathrm{~cm} / \mathrm{s}$ superficial feed slurry velocity and $600 \mathrm{~mm}$ froth height. The performance of flotation column was found to be marginally better than that of the conventional flotation cells in the washery. Also, advantages such as low operational, maintenance and energy costs and operational flexibility in the case of flotation column could lead to financial accruals over a long run.
\end{abstract}

Key words: coal fines; coal flotation; column flotation; coal washery.

\section{Introduction}

Froth flotation is the most efficient and cost-effective separation method for particles within a narrow size range, normally from $50 \mu \mathrm{m}$ to $600 \mu \mathrm{m}$ for coal and exploits the differences in surface properties [1-6]. Froth flotation is a universally accepted physicochemical process for the beneficiation of coal fines [7]. Its separation efficiency depends on the wettability difference between the coal-rich and mineral-rich particles of the coal slurry in the flotation circuit. Generally, the coarse coal has good selectivity, but the flotation rate is slow [7]. Coal flotation makes use of the natural hydrophobicity of the carbonaceous matter in coal [8]. Although coal is naturally hydrophobic, collectors have been used to enhance the hydrophobicity of coal in coal flotation [9]. The upper particle size limit for flotation using novel flotation reagents increases the yield [10]. Large bubbles are needed to provide sufficient levitation of coarse particle-bubble aggregate. Increased surface hydrophobicity promotes recovery of coarse particles by reducing the probability of detachment [11]. Column flotation is a sophisticated froth flotation, which has been developed as an alternative to the conventional, mechanically agitation flotation and it has been claimed that column flotation gives higher recovery with lower ash content [12-13]. The main advantages of the column flotation cells over mechanical ones include excellent separation ability, low capital and operating cost, a less demand for plant space, simple circuit and efficient selfcleaning and adaptability to automatic control $[8,14]$. Also, the performance of the column is superior to that of conventional cell owing to

\#Corresponding author: vasumatisamy@gmail.com 
the presence of large fines in the coal [15-17]. Upgrading of coal in a flotation column can be significantly improved when froth stability is properly controlled through the manipulation of appropriate variables such as gas flow rate, froth height and feed solid concentration [18]. In the present investigation, an attempt has been made to evaluate the performance of a flotation column at pilot plant scale vis-à-vis conventional mechanical flotation cells in an operating coal washery by optimizing process and operating parameters with respect to the pilot plant scale flotation column.

\section{Experimental}

\subsection{Materials}

The coal fines slurry used as feed for the column flotation study was drawn from the feed line to conventional flotation bank while the plant was in operation.
Conditioning of the feed slurry with collector and frother took place in the two conditioners placed just before the column flotation cell. Commercial flotation reagents, Nalflote 88001 and Nalco frother 9840 were used as the collector and frother respectively.

\subsubsection{Size Analysis of feed coal}

Fine coal reporting in the form of slurry to the conditioner-I was subjected to proximate analysis and detailed particle size analysis. The results are shown in Tables $1 \& 2$.

However, the ash distribution was found to be more or less uniform across all the size fractions except that in $-100 \mu \mathrm{m}$. Considerable amount $(16.61 \%)$ of feed consists of $+500 \mu \mathrm{m}$ size coal. The ash content of the feed slurry to flotation column was observed to vary from $24 \%$ to $30 \%$ during the campaign. The presence of high percentage of ash in the Indian coal is one of the setbacks for coal cleaning.

Table 1. Proximate analysis of coal

\begin{tabular}{|c|c|c|c|l|}
\hline Sample & Ash (\%) & Moisture (\%) & Volatile Matter (\%) & Fixed Carbon (\%) \\
\hline Feed coal & 25.67 & 0.85 & 19.51 & 53.97 \\
\hline
\end{tabular}

Table 2. Size analysis of feed coal Head Ash: $25.67 \%$

\begin{tabular}{|c|c|c|c|}
\hline Size $(\mu \mathrm{m})$ & Weight $(\%)$ & Ash $(\%)$ & Ash Distribution $(\%)$ \\
\hline+500 & 16.61 & 32.16 & 20.26 \\
\hline$-500+355$ & 13.58 & 26.95 & 13.88 \\
\hline$-355+212$ & 18.46 & 25.67 & 17.97 \\
\hline$-212+100$ & 22.11 & 23.71 & 19.88 \\
\hline-100 & 29.24 & 25.27 & 28.01 \\
\hline
\end{tabular}

\subsection{Methods}

$0.5 \mathrm{~m}$ diameter and $9.0 \mathrm{~m}$ height flotation column was erected at a suitable location in the washing plant circuit so as to facilitate feeding of fine coal slurry to the flotation column as well as to conventional flotation banks. The details of the flotation column were shown in Figure 1.

Slurry/froth interface was maintained using Differential Pressure Transmitter (DPT) mounted on to the flotation column. The output signal of the DPT is looped to an electro-pneumatic discharge valve through a 
controller. Based on the signal (4-20 mA) given by DPT, the tailings discharge valve will be automatically actuated and accordingly the slurry discharge is maintained. The froth depth could be altered between $50-2000 \mathrm{~mm}$ by changing the setpoint in the controller. Air-only spargers made of stainless steel were used. Wash water was supplied through a spray arrangement at the top of the column and above the froth and monitored by magnetic flow meter. Air flow rate was controlled and monitored by purge rotameter. Feed slurry flow rate was regulated and monitored by a variable frequency drive of feed pump and magnetic flow meter respectively.

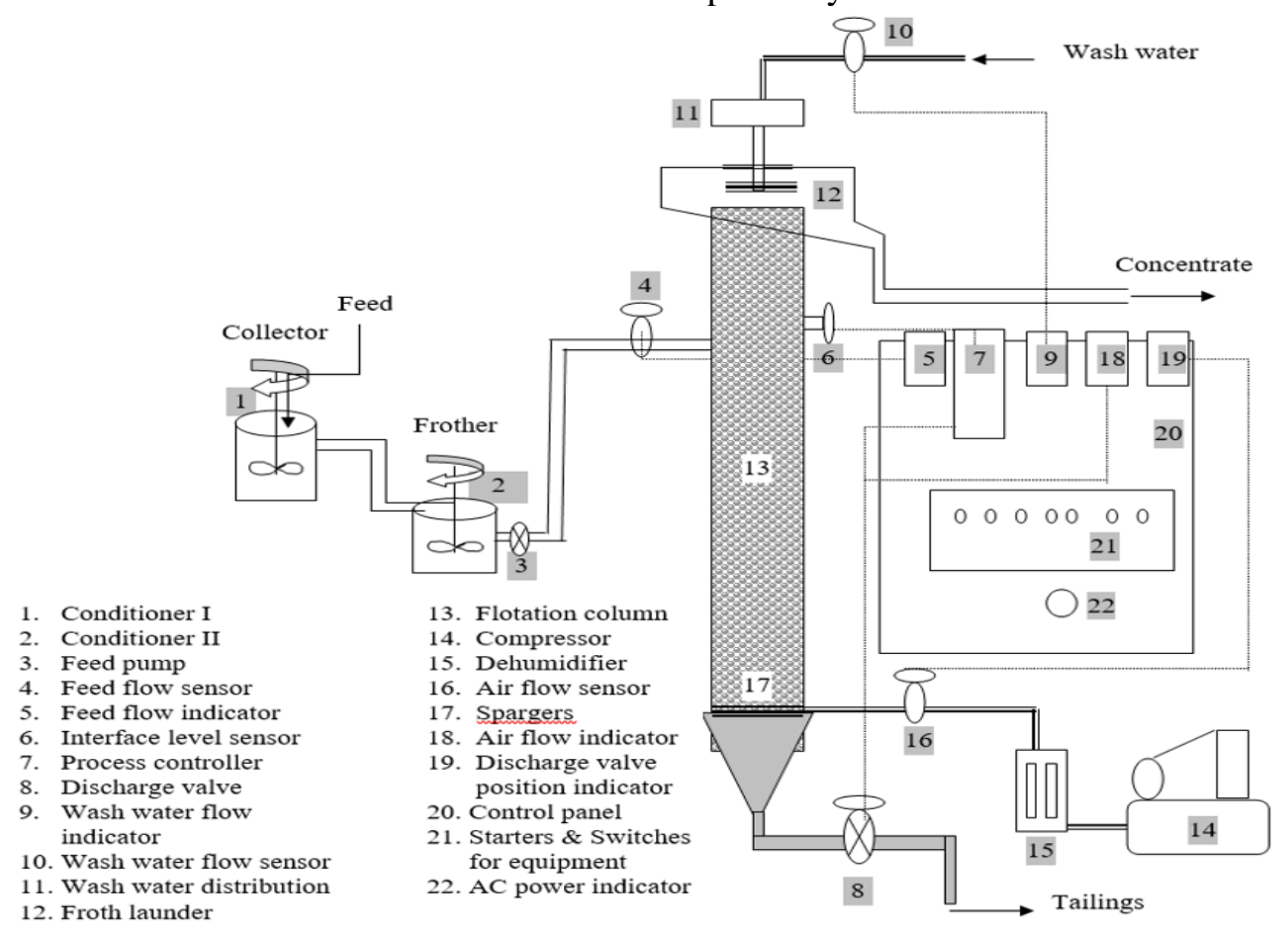

Figure 1. Schematic diagram of $0.5 \mathrm{~m}$ diameter flotation column

The air from the compressor was let into the column at a desired flow rate. The column was filled with water and stabilized at required froth depth. After stabilization with water, the coal slurry (after conditioning with reagents in the conditioners) was pumped into the column at desired flow rate.

The coal slurry which reports to the conventional flotation circuit in the plant was tapped to the conditioner-I in which the collector was added and flows to conditionerII in which frother was added.

Minimum residence time of 10 minutes was maintained at each conditioner. The reagents-conditioned slurry was pumped into the column through a variable frequency driven feed pump. The column was allowed to run for a minimum period of 3-4 residence times (15 minutes). Feed, tailings and concentrate/froth samples were drawn under near-steady state conditions. The collected samples were measured for pulp density, volume of the slurry, weight of the slurry and weight of the solids after drying. Samples were analyzed for ash.

The yield of froth is calculated from

Yield $=[($ Tailings ash \% - Feed ash \%) $] /$ [(Tailings ash\% - Froth ash \%)]. 
Efficiency index of separation (EI) is calculated from

$$
\mathrm{EI}=[(\mathrm{CR}+\mathrm{AR})-100]
$$

where:

CR is combustible recovery (\%) and

$\mathrm{AR}$ is ash rejection (\%) and are calculated using the formulae given below.

$$
\begin{aligned}
& \% C R=\frac{M_{c}\left(100-A_{c}\right)}{M_{f}\left(100-A_{f}\right)} \times 100 \\
& \% A R=1-\left(\frac{M_{c} A_{c}}{M_{f} A_{f}}\right) \times 100
\end{aligned}
$$

where:

$\mathrm{Ac}=$ ash content in concentrate $(\%)$

$\mathrm{Af}=$ ash content in feed (\%)

$\mathrm{Mc}=$ Mass of concentrate $(\mathrm{g})$

$\mathrm{Mf}=$ Mass of feed $(\mathrm{g})$

\section{Results and Discussion}

For efficient operation of the flotation column, optimization of process parameters such as collector and frother dosages and operating parameters such as superficial air velocity, froth depth, superficial feed slurry velocity and superficial wash water velocity is necessary. Initially, the reagents dosages were optimized followed by that of operating parameters.

\subsection{Effect of variation in collector dosage}

Figure 2 shows the results of the effect of varying the dosage of the collector, Nalflote 88001 , on the yield and ash content of the froth/concentrate obtained under a set of fixed parameters as mentioned below.

Parameters:

Frother: $0.042 \mathrm{~kg} / \mathrm{t}$

Superficial feed slurry velocity: $0.57 \mathrm{~cm} / \mathrm{s}$

Superficial air flow velocity: $0.85 \mathrm{~cm} / \mathrm{s}$

Superficial wash water velocity: Nil

Froth height: $200 \mathrm{~mm}$

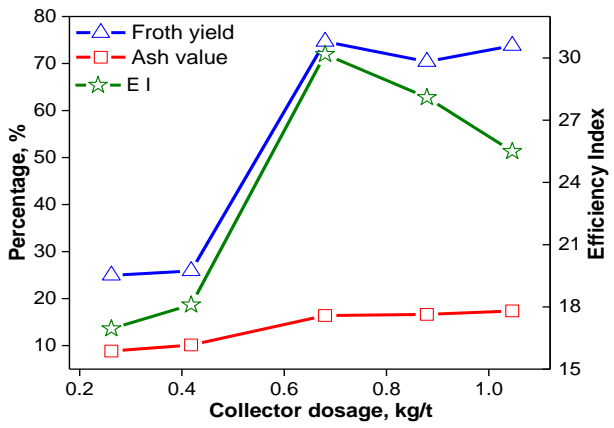

Figure 2. Effect of variation in collector dosage on flotation process

It could be observed from Figure 2 that as the collector dosage was increased from 0.262 $\mathrm{kg} / \mathrm{t}$ to $0.680 \mathrm{~kg} / \mathrm{t}$, the froth ash also increased to $16.40 \%$ with increase in efficiency index of separation from $16.95 \%$ to $30.18 \%$. Correspondingly, the yield also increased from $24.95 \%$ to $74.68 \%$. But as the collector dosage was further increased to $1.046 \mathrm{~kg} / \mathrm{t}$, the froth ash also increased to $17.37 \%$, but the efficiency index of separation decreased to $25.50 \%$. The reason for the lack of selectivity at higher dosages of collector could be due to the in-different (non-selective) adsorption of collector on both coal and ash-forming minerals and also the entrapment of ash in the coal agglomerates [19]. Collector dosage of $0.680 \mathrm{~kg} / \mathrm{t}$ was chosen as the optimum for the optimization of other parameters.

\subsection{Effect of variation in frother dosage}

In this set of tests, frother dosage was varied keeping all the other parameters constant. Figure 3 shows the results of effect of variation of frother dosage on flotation.

Parameters:

Collector: $0.680 \mathrm{~kg} / \mathrm{t}$

Superficial feed slurry velocity: $0.57 \mathrm{~cm} / \mathrm{s}$

Superficial air flow velocity: $0.85 \mathrm{~cm} / \mathrm{s}$

Superficial wash water velocity: Nil

Froth height: $200 \mathrm{~mm}$ 


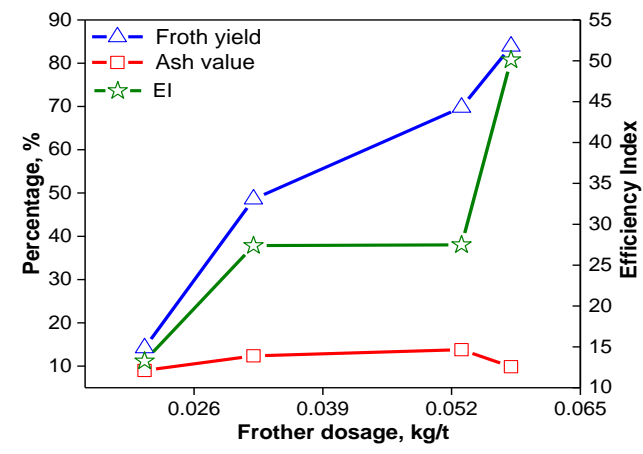

Figure 3. Effect of variation in frother dosage on flotation process

When the frother dosage was increased from $0.021 \mathrm{~kg} / \mathrm{t}$ to $0.058 \mathrm{~kg} / \mathrm{t}$, the yield also increased from $14.20 \%$ to $83.92 \%$ with simultaneous increase in separation efficiency index from 13.26 to 50.12. The ash in froth varied from $8.99 \%$ to $13.78 \%$. It is known that certain frothers also adsorb on coal imparting collecting properties [20]. It appears that the synergistic effect of the collector and higher frother dosage at $0.058 \mathrm{~kg} / \mathrm{t}$ resulted in decrease in froth ash.However, when the frother dosage was increased beyond 0.058 $\mathrm{kg} / \mathrm{t}$, the system entered into negative bias resulting in the entire feed slurry reporting to the froth phase which is undesirable. Hence, frother dosage of $0.058 \mathrm{~kg} / \mathrm{t}$ was chosen as optimum and maintained the same in the subsequent tests.

After optimizing the reagents dosages, the operating parameters of flotation column were optimized by varying one parameter at a time while keeping the others constant.

\subsection{Effect of variation in superficial air flow velocity}

Superficial air flow velocity was varied from $0.77 \mathrm{~cm} / \mathrm{s}$ to $1.19 \mathrm{~cm} / \mathrm{s}$ keeping the test conditions as mentioned below and the results are shown in Figure 4.

Parameters:
Collector: $0.680 \mathrm{~kg} / \mathrm{t}$; Frother: $0.058 \mathrm{~kg} / \mathrm{t}$ Superficial feed slurry velocity: $0.57 \mathrm{~cm} / \mathrm{s}$ Superficial wash water velocity: Nil Froth height: $200 \mathrm{~mm}$

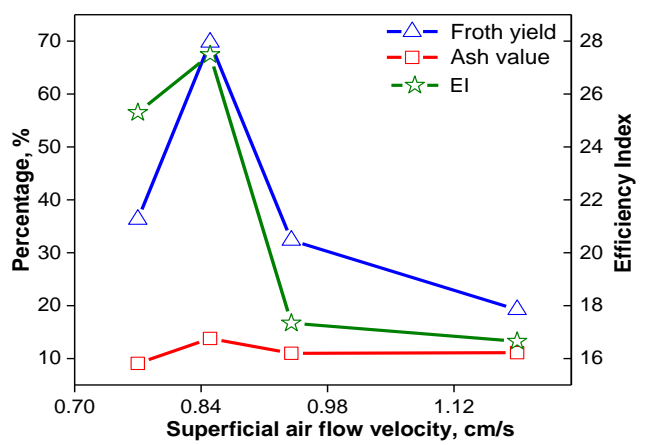

Figure 4. Effect of variation in superficial air flow velocity on flotation process

As the superficial air flow velocity was increased from 0.77 to $0.85 \mathrm{~cm} / \mathrm{s}$, the yield of the froth increased from $36.30 \%$ to $69.79 \%$ while the ash in it increased from $9.08 \%$ to $13.78 \%$ and the separation efficiency index was in the range of $25.30-27.49$. But, as the superficial air flow velocity was further increased to $0.94 \mathrm{~cm} / \mathrm{s}$ and then on to 1.19 $\mathrm{cm} / \mathrm{s}$, there was a fall in the yield as well as in the separation efficiency index. In the initial stages, froth was found to be more stable. But at relatively higher superficial air flow velocity beyond $0.85 \mathrm{~cm} / \mathrm{s}$, the bubbles were found to be unstable leading to froth dropback resulting in lower froth yield. This could also be due to transition of laminar flow of slurry at lower superficial air flow regime $(0.77-0.85 \mathrm{~cm} / \mathrm{s})$ to turbulent flow at relatively higher air flow regime (0.94 - 1.19 $\mathrm{cm} / \mathrm{s}$ ) which could lead to unfavorable separation and lower froth yield.

\subsection{Effect of variation in froth depth}

Froth depth was changed from 200 to 800 $\mathrm{mm}$ and its effect on the process (Figure 5) 
was studied by maintaining the other process and operating parameters constant.

Parameters:

Collector: $0.680 \mathrm{~kg} / \mathrm{t}$; Frother: $0.058 \mathrm{~kg} / \mathrm{t}$

Superficial feed slurry velocity: $0.57 \mathrm{~cm} / \mathrm{s}$

Superficial wash water velocity: Nil

Superficial air flow velocity: $0.85 \mathrm{~cm} / \mathrm{s}$

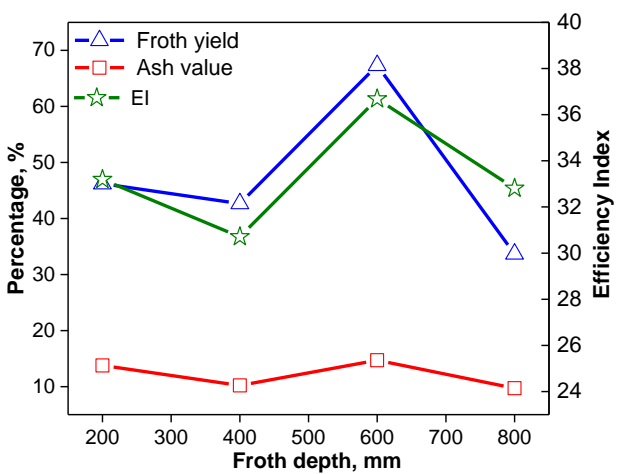

Figure 5. Effect of variation in froth depth on flotation process

At $600 \mathrm{~mm}$ froth depth, maximum yield of $67.33 \%$ could be obtained at $14.71 \%$ ash and at maximum separation efficiency index of 36.68. Below this froth depth, even though froth of relatively lower ash (10.21 - 13.76\%) could be achieved, the respective yields were found to be lower (42.67 - 46.20\%).

When the higher froth depth $(800 \mathrm{~mm})$ was maintained, good quality froth $(9.07-9.72 \%)$ could be generated at relatively lower yield ranging from $33.67 \%$ to $34.17 \%$. The drop in the yield at higher froth depths could be due to the phenomenon of 'froth drop back' wherein the froth drops back into the slurry phase due to excessive built-up of solids in the froth zone.

\subsection{Effect of variation in superficial feed slurry velocity}

Superficial feed slurry velocity was varied from 0.47 to $0.90 \mathrm{~cm} / \mathrm{s}$, keeping all the other parameters constant as shown below.
Parameters:

Collector: $0.680 \mathrm{~kg} / \mathrm{t}$; Frother: $0.058 \mathrm{~kg} / \mathrm{t}$

Superficial air flow velocity: $0.85 \mathrm{~cm} / \mathrm{s}$

Superficial wash water velocity: Nil

Froth height: $600 \mathrm{~mm}$

Superficial wash water velocity: Nil

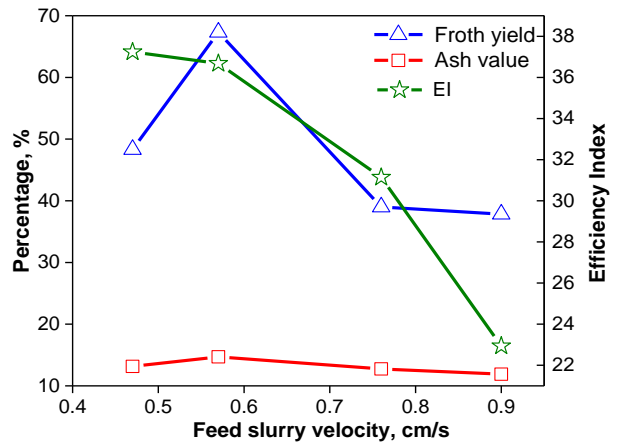

Figure 6. Effect of variation in feed slurry velocity on flotation process

Variation in the superficial velocity of feed slurry affects the residence time of the particles in the system. From the Figure 6, superficial feed slurry velocity of $0.57 \mathrm{~cm} / \mathrm{s}$ slurry velocity, the yield of froth was maximum at $67.33 \%$ with $14.71 \%$ ash. At the lower and higher superficial feed slurry velocities, even though froth of relatively lower ash values could be collected, their respective yields were far lower ranging from $37.84 \%$ to $48.31 \%$. The reason for this could be assigned to insufficient retention time for effective separation to take place.

\subsection{Effect of variation in superficial wash water velocity}

Wash water superficial velocity was varied from 0.47 to $0.90 \mathrm{~cm} / \mathrm{s}$, keeping all the other parameters constant as shown below.

Parameters:

Collector: $0.680 \mathrm{~kg} / \mathrm{t}$; Frother: $0.058 \mathrm{~kg} / \mathrm{t}$

Superficial air flow velocity: $0.85 \mathrm{~cm} / \mathrm{s}$

Superficial feed slurry velocity: $0.57 \mathrm{~cm} / \mathrm{s}$

Froth height: $600 \mathrm{~mm}$ 


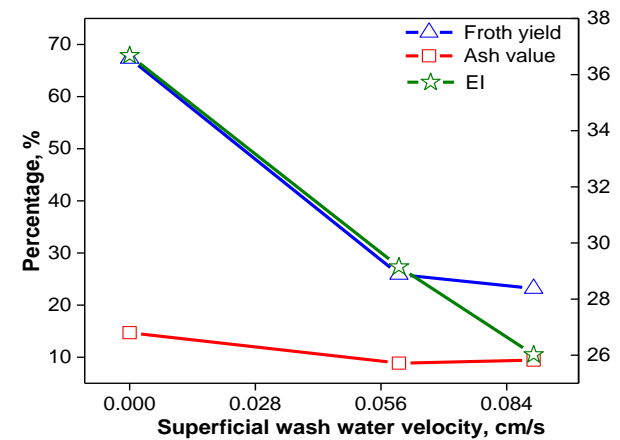

Figure 7. Effect of variation in superficial wash water on flotation process

As the wash water velocity was varied from nil to $0.09 \mathrm{~cm} / \mathrm{s}$ (Figure 7), the yield of the froth or concentrate drastically decreased while the ash level in the froth reduced to less than $10 \%$. The wash water helped in improving the quality of the froth by getting rid of the physically entrapped gangue in the froth lamellae but at highly reduced yield.

The lower yield at increased superficial wash water velocities could also be due to the inability of the free and partially liberated coarser coal particles to stay in the froth due to the continuous stream of wash water, forcing them to report back into the slurry phase along with the water component of the feed slurry.

\subsection{Continuous runs on flotation column at optimized parameters}

Table 3 shows the results of continuous runs, each of minimum 6 hours, on flotation column at optimized parameters. These runs took place on different days while the plant was in operation

Optimized parameters:

Collector: $0.680 \mathrm{~kg} / \mathrm{t}$; Frother: $0.058 \mathrm{~kg} / \mathrm{t}$

Superficial air flow velocity: $0.85 \mathrm{~cm} / \mathrm{s}$

Superficial feed slurry velocity: $0.57 \mathrm{~cm} / \mathrm{s}$

Superficial wash water velocity: Nil

Froth height: $600 \mathrm{~mm}$

Froth of $+70 \%$ yields could be achieved with ash content in the range of 13.33 $14.19 \%$.

Table 4 indicates the comparative performance of flotation column against that of the conventional mechanical flotation cells in the plant.

Table 3. Results of continuous runs on flotation column at optimized parameters

\begin{tabular}{|c|c|c|c|c|c|}
\hline Continuous test (No.) & $\begin{array}{c}\text { Feed ash } \\
(\%)\end{array}$ & $\begin{array}{c}\text { Froth ash } \\
(\%)\end{array}$ & $\begin{array}{c}\text { Tailings } \\
\text { ash }(\%)\end{array}$ & Yield (\%) & EI \\
\hline 1 & 23.80 & 13.33 & 48.71 & 70.41 & 41.10 \\
\hline 2 & 21.59 & 13.15 & 50.57 & 77.45 & 38.62 \\
\hline 3 & 22.65 & 14.19 & 46.50 & 73.82 & 35.64 \\
\hline
\end{tabular}

Table 4. Comparison of performance of flotation column and conventional flotation cells

\begin{tabular}{|c|c|c|c|c|c|c|c|c|}
\hline & \multicolumn{4}{|c|}{ Flotation Column $(0.5 \mathrm{~m} \phi)$} & \multicolumn{4}{|c|}{ Conventional Flotation Cells (Plant scale) } \\
\hline & \multicolumn{3}{|c|}{$\operatorname{Ash}(\%)$} & \multirow{2}{*}{$\begin{array}{c}\text { Yield } \\
(\%)\end{array}$} & \multicolumn{3}{|c|}{$\operatorname{Ash}(\%)$} & \multirow{2}{*}{$\begin{array}{l}\text { Yield } \\
(\%)\end{array}$} \\
\hline & Feed & Froth & Tailings & & Feed & Froth & Tailings & \\
\hline Day 1 & 27.4 & 14.7 & 48.5 & 62.7 & 24.3 & 13.3 & 46.7 & 67.0 \\
\hline Dav 2 & 23.8 & 13.3 & 48.7 & 70.4 & 25.9 & 14.3 & 49.8 & 67.2 \\
\hline Day 3 & 27.4 & 13.6 & 46.2 & 57.8 & 27.1 & 14.8 & 51.2 & 66.1 \\
\hline Day 4 & 23.8 & 14.3 & 49.9 & 72.9 & 26.4 & 15.8 & 50.4 & 69.4 \\
\hline Day 5 & 22.6 & 14.2 & 46.5 & 73.8 & 26.7 & 14.8 & 46.9 & 62.8 \\
\hline Average & 25.0 & 14.0 & 48.0 & 67.5 & 26.1 & 14.6 & 49.0 & 66.5 \\
\hline
\end{tabular}


The results of the conventional mechanical flotation cells reflect the corresponding shifts' average on that particular day. They indicate marginally better performance of a flotation column in comparison to conventional flotation cells.

\section{Conclusions}

A $0.5 \mathrm{~m}$ diameter pilot scale flotation column was installed in an operating coal fines containing $25.0 \%$ ash (average value) could be upgraded to a froth or concentrate of $14.0 \%$ ash with $67.5 \%$ yield and ash in flotation cells in the washery could be improved to a froth of $14.6 \%$ ash. The yield in the flotation circuit was $66.5 \%$ with ash in the tailings at $49.0 \%$. The marginally better performance of flotation column visà-vis the conventional flotation cells could be attributed to maneuverability and greater control over the yield and ash content of the froth depending upon the source/quality of the raw coal and end user requirements. The separation efficiency of flotation column could have been better but for the presence of considerable amount of coarser size coal $(16.61 \%+500 \mu \mathrm{m})$ in the feed.

\section{Acknowledgements}

The authors are grateful to the Director, CSIR - National Metallurgical Laboratory, India for his encouragement and permission to publish the work. The authors would like to thank the management of M/s Tata Steel Limited, India for sponsoring the project, provide logistic support as well as ash analysis of the samples.

\section{References}

[1] Bhattacharya, S., Dey, S. (2008) Evaluation of frother performance in coal flotation: A critical review of existing methodologies, Mineral
Processing and Extractive Metallurgy Review 29, 275-298.

[2] Dey, S., Pani, S. (2013) Effective processing of low-volatile medium coking coal fines of Indian origin using different process variables of flotation, International Journal of Coal Preparation and Utilization 32, 253264.

[3] Humeres, E., Debacher, N. A. (2002) Kinetics and mechanism of coal flotation, Colloid Polymer Science 280, 365-371.

[4] Sobhy, A., Tao, D. (2013) High efficiency nanobubble coal flotation, International Journal of Coal Preparation and Utilization 33, 242256.

[5] Trahar, W. J., Warren, L. J. (1976) The floatability of very fine particles - a review. International Journal of Minerals Processing 3, 103-131.

[6] Xia, W., Yang, J. (2013) Enhancement in flotation of oxidized coal by oxidized diesel oil and grinding pretreatment, International Journal of Coal Preparation and Utilization 33, 257-265.

[7] Chaudhri, S., Sen, R., GowriCharan, T. (2017) Characteristics of an improved collector derived from a waste of coalprocessing plant for the beneficiation of Indian coking coal fines by frothe flotation, International Journal of Coal Preparation and Utilization, 1-11.

[8] Tian, Q., Wang, Y., Li, G. (2017) Application of special collectors and flotation column for beneficiation low rank coal slimes, Physicochemical Problems of Mineral Processing 53 (1), 553-568.

[9] Cheng, G., Gui, X. H., Liu, J. T., Xu, H. X., Wang, Y. T., Zhang, Q. D., Song, A. (2013) Study on size and density distribution in fine coal 
flotation, International Journal of Coal Preparation and Utilization 33, 99-116.

[10] Yoon, R. H., G.H. Luttrell and R. Asmatulu. 2002. Extending the upper particle size limit for coal flotation. The Journal of The South African Institute of Mining and Metallurgy, 411-416.

[11] Tao, D. (2004) Role of bubble size in flotation of coarse and fine particles A Review, Separation Science and Technology 39 (4), 741-760.

[12] Liaoa, Y., Caoa, Y., Hub, Z., Taoc, X. (2015) A new preparation scheme for a difficult-to-float coking coal by column flotation following grinding, The Journal of The South African Institute of Mining and Metallurgy 115, 161-164.

[13] Jena, M. S., Biswal, S. K., Das, S. P., Reddy, P.S. R. (2008) Comparative study of the performance of conventional and column flotation when treating coking coal fines, Fuel Processing Technology 89, 1409-1415.

[14] Hacifazlioglu, H., Hale Sutcu. (2007) Optimization of some parameters in column flotation and a comparison of conventional cell and column cell in terms of flotation performance, Journal of the Chinese Institute of Chemical Engineers 38, 287-293.

[15] Oh-Hyung Han, Min-Kyu Kim, Byoung-Gon Kim, Nimal Subasinghe,
Chul-Hyun Park, (2014) Fine coal beneficiation by column flotation, Fuel Processing Technology 126, 49-59.

[16] Vasumathi. N., Vijaya Kumar, T.V., Ratchambigai, S., Subba Rao, S., Prabhakar S., Bhaskar Raju, G. (2016) Beneficiation of Indian non-coking coal by column flotation, International Journal of Coal Science and Technology 3, 206-214.

[17] Vasumathi. N., Vijaya Kumar, T.V., Ratchambigai, S., Subba Rao, S., Prabhakar S., Bhaskar Raju, G. (2015) Flotation studies on low grade graphite ore from eastern India, International Journal of Mining Science and Technology 25, 415-420.

[18] Tao, D., Luttrell, G. H., Yoon, R. H. (2000) A parametric study of froth stability and its effect on column flotation of fine particles, International Journal of Minerals Processing 59, 2543.

[19] Sis, H., Gulhan Ozbayoglu, Musa Sarikaya (2004) Utilization of fine coal tailings by flotation using ionic reagents, Energy Sources 26, 941 949.

[20] Aplan, F. F. (1976) Coal flotation, In Flotation, Gaudin Memorial Volume 2, (Ed. M. C. Fuerstenau), New York: AIME, 1235 - 1264. 


\title{
OPLEMENJIVANJE FINE KLASE UGLJA PRIMENOM FLOTACIJE U KOLONAMA
}

\author{
N. Vasumathi ${ }^{1 \#}$, T.V. Vijaya Kumar ${ }^{1}$, K. Prasad ${ }^{2}$, S. Subba Rao ${ }^{1}$, \\ S. Prabhakar ${ }^{1}$, G. Bhaskar Raju ${ }^{1}$
}

${ }^{1}$ CSIR - National Metallurgical Laboratory Madras Centre, CSIR Road, Taramani, TTTI (P.O), Chennai-600113, India ${ }^{2} \mathrm{M} / \mathrm{s}$ Tata Steel, Jamshedpur, CSIR Jamshedpur-831001, India

(Primljen: 27. Februar 2018.; Prihvaćen: 31. Maj 2018.)

\begin{abstract}
Izvod
Oplemenjivanje fine klase uglja sa visokim sadržajem pepela izvedeno je u postrojenju za pranje uglja modifikacijom pilot flotacijske kolone prečnika 0,5 mm. Doze kolektora i penušača iznosile su 0,680 kg/t i 0,058 kg/t. Pri ovakvom izboru reagenasa, operativni parametri flotiranja u koloni su takođe optimizovani. Maksimalno iskorišćenje iznosilo je 67,5\% za ciljani nivo sadržaja pepela od $14 \%$, pri sadržaju pelela u ulazu od $25 \%$. Ovaj rezultat je dobijen pri sledećim operativnim parametrima: $0,85 \mathrm{~cm} / \mathrm{s}$ brzina protoka vazduha, $0,57 \mathrm{~cm} / \mathrm{s}$ brzina dovoda pulpe i $600 \mathrm{~mm}$ visina pene. Tehnološki pokazatelji flotiranja uglja u koloni neznatno su bolji od dobijenih pokazatelja u konvencionalnim flotacijskim mašinama. Takođe, prednosti kao što su niski troškovi održavanja, operativni $i$ energetski troškovi, kao i operativna fleksibilnost u slučaju flotacije u kolonama mogu dovesti do finansijskog dobitka tokom dužeg perioda.
\end{abstract}

Ključne reči: fine klase uglja; flotacija uglja; flotacija u kolonama; postrojenje za pranje uglja.

\section{"Kontakt adresa autora: vasumatisamy@gmail.com}

doi: 10.5937/JMMA1801025V 